FILOZOFIA

Roč. 76,2021 , č. 7

DOI: https://doi.org/10.31577/filozofia.2021.76.7.2

\title{
NAOZAJ FREGE PLAGIZOVAL STOIKOV? ${ }^{1}$
}

FRANTIŠEK GAHÉR, Univerzita Komenského v Bratislave, Filozofická fakulta, Katedra logiky

a metodológie vied, Bratislava, SR

GAHÉR, F.: Did Frege Really Plagiarize the Stoics?

FILOZOFIA, 76, 2021, No 7, pp. $499-520$

The similarity between logic and semantics of the Stoics and Frege has long been known, and it can be explained in various ways. In 2021, Susane Bobzien published a work in which she explains this similarity rather surprisingly: she hypothesizes that Frege generously helped himself with the foundations of Stoic logic as it was published in the first volume of History of Logic in the West by Carl Prantl. However, this hypothesis encounters various problems. The key point of the whole accusation is founded on the formulation of a general proposition in language using implication and anaphora, which Frege supposedly took from the Stoics, although in Prantl's text there is only one example of a sentence with this structure. On the contrary, there are many examples of such sentences in contemporary professional (e.g. legal) texts. Many examples of semantic similarities that Bobzien presents are based only on the similarities between isolated concepts; however, that is regularly the case for such concepts with the same conceptual basis. Bobzien presents a significant number of matches only on the basis of results that could allegedly be inferred from the texts. However, this cannot be considered a proof of plagiarism. Bobzien does not consider many sources for the continuity of interpretation such as the so-called hypothetical syllogism found in available textbooks of logic. Last but not least, her claims do not consider many differences between Stoic and Frege's logic. All this leads us to the conclusion that Bobzien does not present sufficient facts and connections between them that would confirm her hypothesis about Frege's plagiarism of the Stoic logic: Frege simply was not a plagiarist.

Keywords: Plagiarism - Stoics - Frege - Logic - Semantics - Propositional logic - Predicate logic

Plagizovanie ako vysvetlenie podobnosti koncepcií?

Podobnost' stoickej sémantiky a logiky s Fregeovou je už dávnejšie známym faktom. ${ }^{2}$ Táto podobnost' môže byt' vysvetl'ovaná najmenej dvoma rôznymi spôsobmi. Frege poznal stoickú sémantiku a logiku priamo, či už z dochovaných prameňov stoických komentárorov, najmä z diel Diogena Laertského a Sexta Empirika (hypotéza

\footnotetext{
${ }^{1}$ Ďakujem kolegovi Vladimírovi Markovi a dvom anonymným recenzentom za cenné pripomienky $\mathrm{k}$ pracovnej verzii state.

${ }^{2}$ Bližšie o tom napríklad Gahér (2000; 24, 29 - 34, 43, 65 - 67; 2006, 27, 32 - 34, 59 - 60, 78 - 83).
} 
A1) či sprostredkovane (A2), alebo ju nepoznal (nejako podrobne) a prišiel k obdobným záverom nezávisle od stoikov (B). ${ }^{3}$ Túto poslednú hypotézu som predpokladal v práci o stoickej sémantike a logike (Gahér 2000, 2006), kde som porovnával obe koncepcie.

Susanne Bobzien v stati s významom nadpisu Frege plagizoval stoikov (Bobzien 2021, 150) uvádza, že si spomenula, že pri príprave hesla o antickej logike pre Stanfordovu encyklopédiu v roku 2006 práve v čase, ked' učila pokročilý kurz o Fregeho filozofii logiky, si v nej všimla tak vel'a paralel so stoikmi, že si nedbalo poznačila vetu: „Množstvo blízkych podobností medzi Chrysippovou filozofickou logikou a tou Gottloba Fregeho je výnimočne nápadné...", s tým, že sa tejto otázke plánovala neskôr venovat' (Bobzien 2021, 150).

V roku 2009 trojica vedcov (jeden klasický filológ a dvaja historici filozofie) Gottfried Gabriel, Karlheinz Hülser a Sven Schlotter napísali článok (Gabriel, Hülser, Schlotter 2009), ${ }^{4}$ v ktorom prišli s odhalením osoby, ktorá mohla Fregemu sprostredkovat' stoickú teóriu: mal to byt' jeho sused, klasický filológ Rudolf Hirzel, ktorý s ním býval v jednom dome dvadsat' rokov a napísal po latinsky prácu o stoickej logike (Hirzel 1879). Dokonca našli fotografiu, na ktorej sedia vedla seba cez uličku v aule v Jene v roku 1908 pri príležitosti osláv 350. výročia založenia univerzity.

Susanne Bobzien sa aj na podnet tejto publikácie vrátila k starému zámeru preskúmat' nápadnú podobnost' stoickej a Fregeho logiky a v prvom kroku kriticky a podrobne preverila zistenia trojice vedcov. Došla k záveru, že ,autori nepredložili žiadnu evidenciu toho, že by Hirzel niekedy hovoril Fregemu o stoickej logike alebo o filozofických problémoch s výnimkou Platónovho Hippiasa väčšieho“ (Bobzien 2021, 152). To posledné je podl'a nej možné, ale zrejme irelevantné. Hypotéza A2 $\mathrm{v}$ tejto konkretizácii nebola potvrdená.

Bobzien však nerezignovala na hypotézu A2 o Fregeho sprostredkovanom poznaní stoickej logiky. Hlavnú hypotézu o plagizovaní sformulovala takto:

„Predpokladám, že Frege plagizoval stoikov v širokej škále svojich prác o filozofii logiky a jazyka, napísaných hlavne medzi 1890 a svojou smrtou v 1925 (väčšina z nich bola publikovaná posmrtne) a možno skôr" $(2021,152)$.

Hoci existenčné hypotézy nemožno kategoricky falzifikovat', predsa môžeme spochybnit' jej textovú evidenciu. Formulácia hypotézy o plagizovaní má však najmenej tri otázne miesta, ktoré ju tak zoslabujú a robia neurčitou, že je vel'mi t’ažké

\footnotetext{
${ }^{3}$ Toto členenie spôsobov, ako sa mohol so stoickou logikou oboznámit', sa určite dá ešte zjemnit', ale na účely nášho článku ho považujeme za dostatočné.

${ }^{4}$ Neskôr v práci Gabriel, Schlotter (2017, 186 a n.) rozšírili okruh autorov, z ktorých údajne Frege mohol čerpat'.
} 
spochybnit' jej evidenčnú bázu: 1) má íst' hlavne o práce publikované medzi rokmi 1890 a Fregeho smrt'ou; 2) má íst' o práce, z ktorých väčšina bola publikovaná posmrtne; 3) môže íst' aj o práce, ktoré vyšli aj skôr, pred rokom 1890.

Ad 1: Hoci by sme vylúčili plagizovanie $\mathrm{v}$ prácach vo vymedzenom období rokov 1890 až 1925, predsa by sme nevyvrátili túto hypotézu.

Ad 2: Hoci Bobzien na konci článku vel'mi zmierňuje svoje závery o Fregeho plagizovaní stoikov, predsa za obsah prác vydaných posmrtne nemôžeme Fregemu nič vyčítat'. A to ani v prípade, že by obsahovali priame výpisky a poznámky z prác stoických prameňov. Bobzien sa odvoláva na Michaela Dummetta a konštatuje, že niektoré posmrtne vydané Fregeho práce (napríklad Kernsätze zur Logik) obsahujú zjavné Fregeho komentáre k prácam iných autorov či presnejšie poznámky z reflexie týchto prác, napríklad z Úvodu diela nemeckého filozofa a logika Hermanna Lotzeho Logik. ${ }^{5}$ Hans Sluga tvrdí, že Frege nadväzoval na Lotzeho Logiku (Sluga 1980, 77 a n.) a podl'a Jeremy Heisa jediný kurz filozofie, ktorý Frege ako študent navštevoval, viedol práve Lotze. Fregeho kolega Bruno Brauch dokonca tvrdil, že sám Frege mu povedal, že Lotzeho dielo malo naňho rozhodujúci vplyv (Heis 2013, 122).

Ad 3: Dôvetok „možno skôr“ posilňuje neurčitost' generovanú modifikáciou hlavne a zbavuje oponenta možnosti bránit' Fregeho pred obvinením z plagizovania argumentovaním na základe jeho originálnych myšlienok, publikovaných v skorších prácach (pred rokom 1890), a ich kontinuity v neskorších prácach. Takto by sa manévrovací priestor oponenta vel'mi zúžil a všetko, čo Frege predložil ako svoju myšlienku a malo by nejakú, čo i len slabšiu alebo domnelú formulačnú či významovú paralelu v stoických prameňoch, by mohlo byt' označené za plagiát. Toto robí z uvedenej hypotézy takmer nevyvrátitel'né hodnotenie a obrana Fregeho je takmer znemožnená. Napriek tomu aj s touto „čast’ou“ hypotézy sa pokúsime vyrovnat', ale za nemenej pravdepodobnú budeme považovat' aj hypotézu, že vo Fregeho prácach vydaných pred rokom 1890 sú jeho originálne myšlienky bez priameho vplyvu stoickej logiky. Tento postup podporuje aj fakt, že hoci prístup k stoickým prameňom nemal výlučne len Frege ${ }^{6}$ ale aj jeho vedeckí rovesníci, pričom je známe, že Frege a mnohí jeho univerzitní kolegovia $\mathrm{v}$ tej dobe vedeli po grécky a po latinsky, predsa nik z nich neprišiel s takým prevratným dielom modernej logiky, akým bolo Fregeho Pojmové pismo v roku 1879.

\footnotetext{
${ }^{5}$ Bobzien (2021, 204); Dummett (1991, 66).

${ }^{6}$ Grécko-latinské vydanie súborného diela Sexta Empirika Sexti Empirici Opera vyšlo v roku 1718 v Lipsku a bolo dostupné v knižniciach; Bekkerova redakcia gréckych Základov Pyrrhonskej skepsy vyšla v roku 1842 a ich Pappenheimov nemecký preklad vyšiel v roku 1877.
} 


\section{Frege sa nevedel poučit' od iných?}

Frege bol povahou nesporne plachý introvert. Podl'a Carnapovho svedectva bol voči študentom odmeraný - nezvykol s nimi vôbec diskutovat' (Frege 2004, 5), na kongresy nemeckých vedcov i na kongresy nemeckých matematikov od istého času (od roku 1903) prestal chodit', čo mu vyčital David Hilbert v osobnej korešpondencii (Frege 1980, 52). Dummett ho zobrazil ako čudáka, ktorý bol vraj príliš originálny na to, aby bol schopný spolupracovat' s inými, ktorý bol hlboko konzervatívny a ktorý - zdá sa - by sa nevedel od nikoho nič naučit' (Dummett 1981a, 661). Keby toto bola naozaj pravda, tak by to bolo v priamom rozpore s hypotézou o jeho možnom plagiátorstve.

Sluga v sérii článkov publikovaných medzi rokmi 1975 až 1987 kritizoval túto Dummetovu charakteristiku Fregeho (Sluga 1975, 1976, 1977, 1984 a 1987). Bobzien na jednej strane uznáva fakt, že propozičná logika sotva bola v devätnástom storočí niekým pochopená pred Fregeho Pojmovým písmom, na druhej strane si jeho originálnost' vysvetl'uje práve možným plagizovaním stoikov, a to z diela nemeckého historika logiky Carla Prantla (Bobzien 2021, 153). K hypotéze, že Frege t’ažil zo stoikov, práve z Prantla ešte pred rokom 1879, sa podrobnejšie vrátime.

\section{Bol Frege úplne izolovaný?}

O Fregeho vedecko-spoločenskej osamotenosti kolujú až legendy. Frege sa podl'a Dummetta cítil izolovaný, nepochopený a nezaradený do súdobého sveta filozofie a matematiky, „,... zomrel ako zatrpknutý človek, ktorý bol nespravodlivo prehliadaný a ktorého životné dielo bolo z väčšej časti neúspešné“" (Dummett 1973, xxv). Tomuto hodnoteniu predsa len niektoré okolnosti v niečom odporujú.

Ponajprv uved'me, že sám Frege si význam svojho diela nepochybne uvedomoval, čo potvrdzujú jeho vlastné slová o svojich rukopisoch v závete $\mathrm{z} 1$. januára 1925 (osvojenému) synovi Alfredovi:

„,... Hoci nie všetko je zlato, predsa tam zlato je. Som presvedčený, že niektoré z nich sa raz budú tešit' ovel'a väčšej úcte než dnes. Zabezpeč, aby sa nič nestratilo. [...] Je to väčšia čast’ toho, čo ti zanechávam“ (Frege, 1979, IX).

Konštatovanie nedostatočného docenenia svojho diela pokladá za dočasné a obsah závetu nevyznieva ako prejav životnej dezilúzie. Claire Ortiz Hillová upozorňuje, že Dummett nedocenil vel'mi bohatú Fregeho korešpondenciu, ${ }^{7}$ ktorá podl'a nej ponúka iný Fregeho príbeh, ako predstavil Dummett (Hill 1995, 152). Frege od

\footnotetext{
${ }^{7}$ Dummett vedel napríklad o rozsiahlej Fregeho korešpondencii s Löwenheimom (Dummett 1973, xxv), ale aj to, že bola pri bombardovaní zničená.
} 
začiatku devät'desiatych rokov devätnásteho storočia viedol bohatú vedeckú korešpondenciu s matematikom Giuseppe Peanom, neskôr s budúcim fenomenológom Edmundom Husserlom, francúzskym filozofom Louisom Couturatom, matematikom Davidom Hilbertom, britským logikom Philipom Jourdainom, Bertrandom Russellom a inými. Len za posledných devätnást' rokov života išlo približne o stopät'desiat listov (Hill 1995, 158), nepočítajúc tie, v ktorých diskutovali o Fregeho diele medzi sebou (Hill, 168).

Aj Pavel Tichý si myslel, že osud k Fregemu a jeho dielu nebol ohl'aduplný a hoci jeho výkon v logike zatienil čokol'vek, čo bolo logikmi vykonané počas predchádzajúcich dvoch tisícročí, zostal osamotený a svojimi súčasníkmi ignorovaný (Tichý 1988, vii). Na rozdiel od Dummetta však na Fregeho hlavné idey nadviazal vypracovaním originálneho systému transparentnej intenzionálnej logiky (1988).

Písomný prejav vyhovoval Fregeho introvertnému naturelu - dával mu dostatok času na podrobné a dôkladné premyslenie problémov, a tak mu umožňoval presne formulovat' otázky a námietky. Ked'že vel'mi často išlo o neúprosnú vecnú kritiku či otázky, ktoré odhal'ovali mnohé nedostatky v dielach druhého korešpondenta, ktorým bol často uznávaný odborník, málokedy druhá strana prejavovala spokojnost'. Napríklad spomínaný Hilbert na mnohé z jeho trefných námietok a otázok nevedel pohotovo odpovedat' a vyhováral sa, že je zavalený inou prácou (Frege 1980, 48). Frege bol pri výmene názorov vedených písomnou formou silný protivník. Brilantnú kritiku Russellovho konfúzneho chápania propozičnej funkcie a premennej obsahuje napríklad list Jourdainovi z januára 1914 (Frege 1980, 82 a n.).

Za zmienku tiež stojí, že nasledovník Ernsta Abbého na výskumnom oddelení pre firmu Carl Zeiss Jenna fyzik Siegfried Czapski pokladal Fregeho za najvýznamnejšieho myslitel'a univerzity v Jene (Frege 2004, 22). Môžeme uzavriet', že Frege napriek uzavretej povahe bol schopný prevziat' myšlienky iných, a teda nebol a priori imúnny voči plagizovaniu.

\section{Plagiátorstvo, zdroj, rozsah}

Ked’že zdrojový text je napísaný v gréčtine alebo v latinčine (antickí stoickí komentátori) a ciel'ový v nemčine, uvažovaný fenomén plagiátorstva v hypotéze A1 sa netýka neoprávneného preberania textu, ale jeho významu. Preverovanie, dokazovanie či vyvracanie $\mathrm{v}$ tomto prípade musí byt' zamerané na rovinu zložených významov a ich štrukturálnej podobnosti.

V prípade hypotézy A2 by mohlo íst' aj o preberanie rôznych častí textu, ked’že hlavné diela antických stoických komentátorov boli preložené do nemčiny a rovnako v nemčine boli aj komentáre k nim. To je prípad hypotézy, ktorú predložila Bobzien: 
Frege si vel'koryso pomáhal základmi stoickej logiky ako boli prezentované v prvom zväzku monumentálnych štvordielnych Geschichte der Logik im Abendland Carla Prantla, publikovaným v roku 1855 (Bobzien 2021, 152).

V takmer stostranovej kapitole o stoickej logike sú v rozsiahlych poznámkach uvedené grécke a latinské pramenné texty. Bobzien špecifikuje svoju hypotézu a predkladá dôvody, prečo za výlučné textové východisko Fregeho poznania stoickej logiky považuje s vysokou pravdepodobnostou práve Prantlovu kapitolu o stoickej logike (Bobzien 2021, 154 a n.).

Komplikáciou pre celé zdôvodnenie plagiátorstva je, že výsledná prezentácia podobností medzi stoickými a Fregeho formuláciami a myšlienkami je v angličtine a čitatel', ktorý si nevie preverit' tieto prípady v nemčine, a ani stoické vzory v origináli (v gréčtine či latinčine), musí dôverovat' autorke, že je nezaujatá a že jej prezentácia je presná a neskreslená. Otázka adekvátnosti prezentácie zhôd je však legitímna. Snažili sme sa preverit' vel'kú čast' jej zistení, ktoré predkladá ako prípady nápadnej analógie, a pri mnohých z nich sme narazili na značné nezrovnalosti a pri niektorých z nich poukážeme na okolnosti, ktoré môžu vyvolat' vážne pochybnosti o tom, či ich autorka prezentovala adekvátne.

\section{Čo je minimálnou jednotkou zhody v prípade plagiátu}

V prípade možného plagizovania vedeckých objavov v podobe vedeckých teórií je priestorom záujmu najmä sémantická a metodologická stránka porovnávaných koncepcií. Pritom kl'účovou je zrejme otázka, aká vel'ká má byt' jednotka významu, metódy či procedúry, ${ }^{8}$ aby sme mohli s dostatočnou istotou tvrdit', že v prípade zhody vo vyjadrení východiskového a výsledného textu (v rôznych alebo totožných jazykoch) ide o plagiát. Bobzien vychádza zo slovníkovej definície plagiátorstva, ktorá je len prvým priblížením k tomuto pojmu. ${ }^{9}$ Pokúsime sa trochu bližšie charakterizovat' tento pojem, ale nemáme dostatočný priestor ani čas, aby sme dokázali predložit' jeho exaktnú definíciu.

Najmenšou jazykovou jednotkou, kde už môže byt' identifikovaná každá zložka významu a spôsob spojenia týchto zložiek, čiže kompletná procedúra, je plnovýznamová neskrátená veta. V niektorých prípadoch to môže byt' aj torzo vety, pokial' sa z neho a z pridruženého textu dá jednoznačne rekonštruovat' celý jej význam. Nestačí len významová zhoda podmetových alebo prísudkových častí viet samostatne.

\footnotetext{
${ }^{8}$ Bližšie o tom Gahér (2016).

${ }^{9}$ Plagiarism: 'the practice of taking someone else's work or ideas and passing them off as one's own. The Oxford Dictionary of Phrase and Fable (Knowles 2006).
} 
Rovnako nestačí totožnost' ani vel'ká podobnost' vyjadrenia jedného pojmu či spojenia dvoch pojmov ako zložiek propozičnej konštrukcie, ani vyjadrená zhoda niektorých čiastkových podprocedúr, pokial' celá propozičná procedúra - konštrukcia - je dost' bohatá. $V$ opačnom prípade by sme našli plagiáty vlastne všade, kde ide o výskum rovnakého predmetu, a to rovnakými či podobnými metódami, ved' základné jednotky celého inštrumentária - pojmy - musia byt' rovnaké bez ohladu na odlišnosti jazykového vyjadrenia. Pri vedeckých objavoch by pri plagizovaní išlo o zhodnú klúčovú myšlienku, zhodnú kompletnú metódu. Nebudeme skúmat' právnu stránku problému a trápit' sa napríklad dokazovaním či vyvracaním jedného z pojmových znakov plagiátorstva - úmysel získat’ prospech či úžitok.

\section{Majú sa aj logické dôsledky formulácií pokladat' za plagiát?}

Dôležitou otázkou posúdenia možného plagiátu je, či sa máme zaoberat' aj porovnávaním zhodnosti logických dôsledkov inak textovo nezhodných formulácií s odlišným priamym či bezprostredným významom. Ak áno, tak by sme vlastne vylúčili možnost', že niekto nezávisle objaví obsahovo zhodnú či vel'mi podobnú teóriu ako niekto iný. To, že sa to v histórii poznania udialo - napríklad objav infinitezimálneho počtu (G. W. Leibniz, I. Newton) a objav systému prirodzenej dedukcie (G. Gentzen, S. Jaśkowski) - nás presvedčuje, že túto hypotézu aj pri jej malej pravdepodobnosti nesmieme vylúčit'. Fregemu sa niečo vel'mi podobné stalo v súvislosti so symbolizáciou aritmetiky. Peano napísal v časopise Rivista di matematica recenziu Fregeho prvého dielu Grungesetze der Arithmetik (1893) (Peano, 1895) a vyzdvihol v porovnaní s ním prednosti vlastného systému Arithmetices principia: nova methodo exposita (1889). Frege v liste Peanovi z 29. 9. 1896 (Frege 1980, 112 a n.) kriticky analyzoval túto komparáciu systémov formalizácie aritmetiky a upozornil ho na to, že jeho (Peanova) symbolizácia v skutočnosti využíva viac základných znakov ako on a niektoré dôležité rozlíšenia v nej chýbajú. Peano hlavné výhrady v odpovedi (Peano 1896) akceptoval (Frege, 1980, 118). Obsah oboch listov bol publikovaný v časopise Rivista di matematica (Frege 1896; Peano 1896). Logické dôsledky oboch symbolizácií aritmetiky sa značne prekrývali, ale obe vznikli nezávisle od seba. To je jeden príklad z mnohých, prečo nebudeme vyhodnocovat' ako nápadné zhody rovnaké logické dôsledky stoickej a Fregeho logiky. Ešte jeden poučný príklad uvedieme.

\section{Znevažovaná logika mala byt' prameňom plagizovania?}

Jedna závažná „ideologická“ okolnost’ stojí proti hypotéze, že Frege si pomáhal stoickou logikou na základe Prantlovho diela - ide o neuveritel'ne znevažujúce hodnotenie stoickej logiky z pera samého Prantla: „O stoickej logike a jej najvýznamnejšom 
predstavitel'ovi Chrysippovi ešte v druhom vydaní svojich Geschichte der Logik im Abendlande z roku 1927 nemecký historik Prantl píše ako o ,vzore zadubeného školometstva' a vyjadruje radost' nad tým, že tento marazmus formalizmu sa v stredoveku nerozšíril“10 (Gahér 2000, 1; 2006, 2).

Odkliatie stoickej logiky publikoval Jan Łukasiewicz práve až v roku tohto druhého vydania (Łukasiewicz 1927). Keby si Frege naozaj bol intenzívne pomáhal stoickou logikou, tak by vlastne svojím presvedčením o správnosti stoickej logiky a sémantiky zázračne predvídal aj Łukasiewiczov objav. Na túto otázku Bobzien neponúkla žiadnu odpoved' okrem neurčitej poznámky, že niektoré detaily zakladali toto (Prantlovo negatívne) hodnotenie ako historicky prijatel'né (Bobzien 2021, 152).

\section{Predikátová logika a všeobecné propozície v jazyku}

Bobzien konštatuje, že výsledok textového porovnania prekračuje stodvadsat' prípadov podobností (bez podobností v epistemológii a usudzovaní), čo vel'mi silne poukazuje na to, že na Fregeho mala vplyv stoická logika (Bobzien 2021, 202). Bobzien jednotlivé paralely triedi podl'a tém, ktorých sa týkajú, a rozlišuje tri obdobia - Fregeho tvorbu pred rokom 1890, do roku 1925 a tretie obdobie posmrtných publikácií. Je zaujímavé, že najviac nápadných zhôd sa podl’a nej týka prác vydaných po roku 1918 na sklonku Fregeho života (zomrel v roku 1925), ked’ originálny systém logiky bol už desiatky rokov predtým publikovaný, alebo posmrtne.

Zámerne začneme jej poslednou témou z prvého obdobia, ktorou je predikátová (prvorádová) logika. Nielen preto, lebo je to najkontroverznejšia téma, ale aj preto, lebo pred viac ako dvadsiatimi rokmi sme prišli s hypotézou, ktorá bola dovtedy v odbornej literatúre neznáma či neprijímaná, a to, že stoici vybudovali fragment predikátovej logiky, a predložili sme jej zdôvodnenie (Gahér 2000, 239 a n.; 2006, 273 a n.). V tomto zmysle by sme Bobzienovej čiastkovú hypotézu mali vlastne privítat'. Centrálnym bodom tejto diskusie je otázka vyjadrenia všeobecnej propozície.

Stoici preferovali formuláciu pomocou implikácie a anaforickej väzby, kde anaforicky použité zámeno to (ten, tá) môže byt' vynechané:

(1) Ak je niečo človekom, tak (to) je smrtelnou rozumnou živou bytostou.

Práve touto vetou Bobzien začína v provnávacej tabul'ke V̌̌eobecnost' v stípci Stoici a ako prameň uvádza Sexta Empirika z knihy Proti etikom (M XI, 11. 8 - 11).

Stoici odmietali formuláciu v zmysle aristotelovskej paradigmy so všeobecným kvantifikátorom:

${ }^{10}$ Prantl $(1927,408)$. Prantl zomrel v roku 1888. 


\section{(2) Každý človek je smrtel’nou rozumnou živou bytost'ou.}

Jedným z dôvodov bolo odmietanie Aristotelovho predpokladu existenčného importu - empirickej neprázdnosti subjektového pojmu (človek) v takejto vete ako nutný predpoklad jej pravdivosti (Gahér 2000, 253 a n.; 2006, 293 a n.).

Frege už v Pojmovom písme $(1879, \S 11)$ pracuje s oboma spôsobmi formulovania všeobecnosti a pokladá ich za významovo rovnocenné. Práve implikatívna formulácia vysvetl'uje záhadu, prečo je vo formálnom jazyku predikátovej logiky od čias Fregeho implikátor, hoci v aristotelovskej formulácii so všeobecným kvantifikátorom sa nevyskytuje.

O tom, čo vyjadruje takáto implikatívna formulácia, sa viedli a ešte aj vedú spory, ${ }_{11}^{11}$ pričom drvivá väčšina učebníc logiky s touto formuláciou stále nepočíta. Odkial' ju teda mohol mat' Frege? Naozaj z Prantla? Ale ved' Bobzien neuvádza, kde v Prantlovi sa táto veta vyskytuje, pretože sa tam jednoducho nevyskytuje. Uvedenie prvej formulácie vyjadrenia všeobecnej propozície (1) je klamlivé a nijako nepodporuje jej hypotézu. To si však menej pozorný čitatel' nemusí všimnút' a podl'ahne dojmu, že Frege to z Prantla mohol opísat'.

Druhá z celkovo dvoch viet, ktoré spomína Bobzien, uvádza v tabul'ke V̌seobecnost' zo stoických prameňov, je Cicerova formulácia známej veštby (De Fato, VI 12, VIII 15) s rovnakou štruktúrou:

(3) Ak sa niekto narodil pri východe Síria, tak ten v mori nezomrie. ${ }^{12}$

Tá sa už u Prantla nachádza v poznámke (456, pozn. 147). S tou sa Frege mohol oboznámit' aj na hodinách latinčiny, ale takáto skúsenost' by sotva stačila na to, aby ju Frege zobral ako základný vzor. To je nepravdepodobné, rovnako ako keby si prečítal Prantla a na základe príkladu jedinej vety (nie dvoch viet, ako si mohol mysliet' nepozorný čitatel') by zvolil implikatívnu reglementáciu všeobecných propozícií v symbolickom zápise.

V knihách o logike, ktoré mohol Frege čítat pred napísaním Pojmového pis$m a$, nenájdeme v popredných častiach expozíciu nejakej ucelenej podoby výrokovej logiky. Ale v zadných častiach či menej výstavných komorách týchto diel čo-to z výrokovej logiky len nájdeme. V učebniciach logiky už u Boethia, ale najmä od

\footnotetext{
${ }^{11}$ Napríklad U. Egli na rekonštrukciu stoickej logiky používa dynamickú predikátovú logiku v podobe, ako ju rozpracovali J. Groenendijk a M. Stokhof, a anaforickú väzbu rekonštruuje pomocou existenčného kvantifikátora, ktorý neviaže premennú v konzekvente: $(\exists x)(\mathrm{S}(\mathrm{x}) \rightarrow \mathrm{M}(\mathrm{x}))($ Gahér 2006, 285 a n.).

${ }^{12}$ Fraňo $(2013,175,177)$. V latinskom origináli je však aj odkazovacie zámeno v úlohe anaforického odkazu. Bližšie o tom Marko (220, 687 a n.).
} 
čias renesancie, sa okrem preferovaného aristotelovského kategorického sylogizmu a rôznych epistemických otázok prezentoval aj takzvaný hypotetický sylogizmus. ${ }^{13}$ Pod týmto názvom sa skrývala výroková (propozičná) logika, ktorá „,... prežívala niekedy zamaskovaná $\mathrm{v}$ schémach a príkladoch $\mathrm{z}$ kategorického sylogizmu a bola niekedy takmer nepostrehnutel'ná“" (Gahér 2019, 267 a n.). Napríklad v opakovane vydávanom latinskom kompendiu Henryho Aldricha (Aldrich 1750, 56), preloženom neskôr aj do angličtiny, nájdeme príklad na konkretizačný modus ponens:

(U1) Ak je niekto múdry, tak ten je cnostný.

(Tento) je múdry.

Teda (tento) je cnostný.

so všeobecnou implikačno-anaforickou premisou, čo zretel'ne poukazuje na skryté prežívanie stoickej paradigmy.

Z diel nemeckých autorov bola Fregemu dostupná napríklad Logika Christopha Sigwarta (1873), čo potvrdzuje aj Fregeho životopisec Lothar Kreiser $(2001,290)$. Sigwart v $\S 36$ o hypotetických súdoch (Sigwart 1889, 281) uvádza príklad všeobecného súdu:

(4) Čo je človekom, to je smrtelné.

Ked' analyzuje nečasový význame spojenia wen-so, konštatuje, že s tým prišli stoici ako prví (Sigwart 1889, 285). Sigwart si uvedomuje možnost' vyjadrenia všeobecnosti pri neurčitom subjekte a uvádza ako paradigmatický príklad vetu:

(5) Ak je niečo telesné, tak je rozpriestranené. (Sigwart 1889, 292)

Pritom jednoznačne konštatuje, že sa tým nevyjadruje nič iné ako všeobecný kategorický výrok (propozícia)

(6) V̌̌etky telesá sú rozpriestranené.

alebo výrok tiež s rovnakým významom:

(7) Čo je telesné, to je rozpriestranené. (Sigwart 1889, 293)

Čiže pri pozornom čítaní tejto známej učebnice si Frege mohol tento starý nápad l'ahko osvojit' z viacerých príkladov viet, ktoré boli predkladané ako paradigmatické

${ }^{13}$ Neskôr bol k nemu pridávaný disjunktívny a zmiešaný sylogizmus. 
pre implikatívne spojenie a nemusel byt' priam zázračne očarený jednou jedinou vetou z Prantla.

Keby aj Frege nebol inšpirovaný týmito alebo podobnými formuláciami z iných učebníc, stačilo by prekročit' hranice logickej spisby, rozhliadnut' sa okolo seba a pozriet' sa napríklad na formulácie ustanovení zákonov. Zdanlivý relikt formulovania všeobecnej propozície pomocou implikácie a anafory je jednou zo štandardných foriem vyjadrovania ustanovení právnych noriem nielen dnes, ale je to tradícia, ktorá má kontinuitu od čias rímskeho práva s predpokladaným stoickým vplyvom. Napríklad v pruskom zákonníku (Landrecht), platnom už od roku 1794, ktorý obsahoval okrem občianskeho práva vlastne takmer kompletné hmotné právo (aj trestné a pod.), je takých štrukturálne zhodných formulácií vel'a - pars pro toto z tých na prvých stranách:

\section{§. 14. Wenn aus Einer Geburt zwey oder mehrere lebendige Kinder zur Welt kommen, so haben dieselben, in der Regel, völlig gleiche Rechte. \\ §. 34. Wer einmal gelebt hat, dessen Tod muß bewiesen werden, wenn über schon erworbne Sachen und Rechte desselben, als eines Verstor- bnen, verfügt werden soll. ${ }^{14}$}

Takže problémom nebolo, či sa Frege mal odkial' inšpirovat' k vyjadrovaniu všeobecnej propozície pomocou implikácie a anafory - zdrojov bolo dostatok a vôbec nebol odkázaný na jedinú vetu v poznámke pod čiarou z Prantla.

\section{Mal Frege na prvý pohl'ad odhalit' to, čo Bobzien pôvodne nezbadala ani pri} podrobnom štúdiu?

Hlavným problémom bolo, ako obe formulácie pôvodne z dvoch rôznych paradigiem konzistentne zachytit' $v$ jednom symbolickom jazyku a $v$ jednej komplexnejšej teórii. Že na to nestačilo poznat' stoické texty z Prantla, svedčí aj jeden poučný príbeh historičky logiky, ktorý začal pôvodne neadekvátnym pochopením stoickej logiky. Prvú čast' príbehu opíšeme podrobnejšie. Práve v roku 2000, ked' sme finišovali s publikovaním práce, ktorá obsahovala hypotézu o tom, že stoická logika je predikátovou logikou, ktorá obsahuje propozičnú logiku, Bobzien publikovala rozsiahlu stat', kde predložila rekonštrukciu úplného sylogizmu a na rozdiel od nás v ňom nevidela úsudok predikátovej logiky, ale výrokovej logiky (Bobzien 2000, 88). Išlo o úsudok, ktorý Aristoteles nepovažoval za sylogistický:

\footnotetext{
14 Erster Theil: Allgemeines Landrecht für die Preußischen Staaten (1. 6. 1794). Dostupné online na: opinioiuris.de
} 
Ak: ak jestvuje človek, tak nutne jestvuje živočích, a ak jestvuje živočích, tak nutne jestvuje podstata, tak: ak jestvuje človek, tak nutne jestvuje podstata. ${ }^{15}$

Tento úsudok sa snažili nasledovníci Aristotela pretransformovat' na úsudok kategorického sylogizmu, ale nedarilo sa im to, pričom Theofrastos v ňom videl nasledujúcu úsudkovú formu (schému):

(UF1) Ak A, tak B; ak B, tak C; teda ak A, tak C. ${ }^{16}$

K tomuto záveru sa po zložitých analýzach nakoniec priklonila aj Bobzien. Išlo však o chybu, ktorá sa reprodukovala takmer dve tisícročia a odhalená bola až po Fregeho smrti Janom Łukasiewiczom (1927). To, že s tým zápasili aj Sigwartovci otec aj syn -, môžeme l'ahko demonštrovat'. V príručke logiky uvádza Heinrich Sigwart - otec Christopha, že základná schéma podmienkového spojenia má formu Wenn A ist, so ist $b$ (Sigwart 1835, 104). Nie je zrejmé, čo v tejto formulácii znamená slovo ,je“ (ist). Už nemôže íst’ o vyjadrenie existencie, ani o číru kopulu. Syn Christoph Sigwart v tret’om vydaní svojej Logiky uvádza pri zmiešaných hypotetických úsudkových schémach formulácie s ,plati““ (gilt):

(UF2) Ak platí A, tak platí X. ${ }^{17}$ A platí. / Teda X platí. (Sigwart 1889, 424)

a

(UF3) Ak platí A , tak platí X. X neplatí. / Teda A neplatí. (Sigwart 1889, 425)

Aj v týchto formuláciách je slovo platí nadbytočné, ale dá sa mu rozumiet' ako vyjadreniu platnosti, pravdivosti hodnôt premenných $\mathrm{A}, \mathrm{X}$ - pri vel'mi ústretovom čítaní môžeme znaky $\mathrm{A}, \mathrm{X}$ chápat' ako výrokové premenné. Problém povahy premenných $\mathrm{A}, \mathrm{B}, \mathrm{C}$ je vypuklý aj pri preformulovaní všeobecného výroku kategorického sylogizmu na hypotetický: $\mathrm{v}$ poznámke o tzv. čistom hypotetickom sylogizme a jeho variantoch vystupujú $\mathrm{A}, \mathrm{B}, \mathrm{C}, . ., \mathrm{X} v$ úlohe výrokových premenných, ale pri formulácii nepodmienkového všeobecného súdu ide o predikátové premenné $(1889,438)$. Túto chybu reprodukuje aj Prantl pri uvádzaní stoických úsudkových schém zo Sexta ${ }^{18}$

${ }^{15}$ Aristoteles (Anal. pr. I., xxxii, 47a, $28-31$ ).

${ }^{16}$ Bližšie o tom Gahér (2006, 273 a n.).

${ }^{17}$ Wenn A gilt, so gilt X.

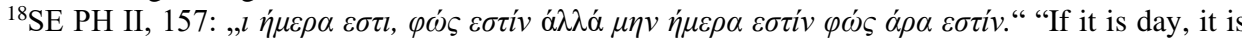
light but in fact it is day; therefore it is light." Wenn das Erste ist, ist das Zweite. Das Erste aber ja ist. Also ist das Zwei. 
(Prantl 1855, 473). Toto viac ako dvojtisícročné nedorozumenie ešte v roku 2000 Bobzien neodhalila.

My sme vtedy navrhli inú rekonštrukciu, ktorá vo všetkých troch vetách identifikuje vyjadrenie všeobecných propozícií, ktoré sa nedajú rozložit' na implikatívne spojenie dvoch samostatných existenčných propozícií, ktoré by si zachovali pôvodný význam. To napríklad znamenalo, že v prvej premise sme „zbadali“ všeobecnú propozíciu:

(8) Ak je niečo človekom, tak je živočichom.

To otváralo cestu pre integrovanie celého kategorického sylogizmu do stoickej logiky, ktorá prekračovala rámec výrokovej logiky a uvedený úsudok bol úsudkom stoickej predikátovej logiky:

(U2) Ak je niečo človekom, tak ono je živočíchom.

Ak je niečo živočíchom, tak ono je podstatou.

Ak je niečo človekom, tak ono je podstatou.

A to bol už len krôčik ku formulácii predikátového (konkretizačného) modus ponens, ktorý však prekračuje možnosti kategorické sylogizmu:

(U3) Ak je niečo človekom, tak ono je živočíchom.

Dión je človek.

Dión je živočích.

Je preto prekvapivé, že Bobzien, ktorá toto naznačenie predikátovej logiky v antických textoch sama napriek intenzívnemu skúmaniu vtedy nezbadala, ${ }^{19}$ Fregemu túto schopnost' pripisuje na základe údajného prečítania jedného jediného textu a príkladu jedinej vety $\mathrm{v}$ ňom.

\section{NeúpIný predikát verzus nenasýtená funkcia}

Ďalšou témou údajne nápadných podobností majú byt' charakteristiky, ktoré sa týkajú obsahu, významu viet. Stoici v prípade zložiek propozícií (axiómata) hovoria o neúplnosti (ellipé) významu, Prantl to prekladá ako mangelhafte $(1855,438)$. Pri hovorení o štruktúre propozície Frege použiva výrazy unvollständig, ergänzungsbedürftig (Frege 1993, 72), teda neodpisuje od Prantla ani neprekladá stoikov z Prantla. Naopak, často si pomáha termínom z vtedajšej chémie vo význame nenasýtenosti:

${ }^{19}$ V práci Bobzien, Shogry $(2020,131)$ už prezentujú názor, že stoici vyjadrovali vety aj s viacnásobnou všeobecnost’ou a pracovali s nimi v platných úsudkoch. 
ungesättigte Teile des Gedankens („,nenasýtené časti propozície“) - v tomto článku pätkrát (Frege 1993, 72). Toto spojenie použil aj v stati Pojem a funkcia (Frege 1891) trikrát a v článku $O$ pojme a predmete (Frege 1892b) pätkrát. Táto metafora nenasýtenosti ako základná charakteristika funkcie je nosná pre Fregeho vysvetlenie rozdielu (významom vlastného mena, resp. významom výroku - myšlienkou). Frege ako prvý prišiel s návrhom aplikovat' $\mathrm{v}$ matematike rozpracovaný pojem funkcie na analýzu prirodzeného jazyka a nahradit' dvojicu subjekt-predikát dvojicou argument funkcie-funkcia. Preto je zavádzajúce, ked'v tabul'ke zhôd na strane stoických formulácií medzi funkciou (napríklad významom predikátu alebo vetnej spojky) a predmetom Bobzien uvádza spojenie predikát ako funkcia (Predicate as function 2021, 156), ktoré vnucuje zhodu s Fregeho originálnym prístupom z Pojmového písma (1879). Bobzien uvádza, že toto sa zakladá na texte z Diogena Laertského o neúplnom obsahu (VII, 69 - 70). Ale pojem funkcie, s ktorým pracuje Frege, má zretel'né korene až u Reného Descarta v jeho analytickej geometrii a algebre, predpokladat' ho u stoikov je ahistorizmus. Takýmto bezbreho „ústretovým“ postupom by sme však mohli vidiet' v stoickej logike hádam všetko, čo Frege objavil alebo čo by nám napadlo. Rovnako zavádzajúco pôsobia aj spojenia, ktoré sú uvedené v stípci pod stoikmi o dvojito nenasýtených alebo binárnych predikátoch, ktoré sú z pera Bobzien a Shogry. Ved' to je akoby opačný smer plagizovania - stoikom vnucujeme Fregeho terminológiu. Ked'že v týchto dvoch častiach (Všeobecnost'; Obsah) boli uvedené hlavné príklady zhôd z Fregeho prác pred rokom 1890, môžeme to uzatvorit' negatívnym konštatovaním: Bobzien nepredložila žiadny relevantný príklad zhôd Fregeho prác pred rokom 1890 so stoickými prameňmi v Prantlovi. Originalita Fregeho výkonu v Pojmovom pisme nie je vôbec poznačená podozrením z plagiátorstva.

\section{Významová zhoda vysekaných krátkych ret’azcov textov?}

Bobzien doslova rozsekáva grécky text v Prantlovi na vel'mi malé nevetné ret'azce len preto, aby vzbudili v čitatel'ovi dojem, že sa na ne naozaj podobajú úryvky Fregeho textu. Napríklad jedna strana z Prantla (Prantl 1855, 441) je zdrojom 21 údajných zhôd, ${ }^{20}$ pričom v samom Prantlovom šest'riadkovom komentári v nemčine sú ako príklady nápadných zhôd len dve krátke spojenia Wahr und Falsch a coordinirte Arten. Význam prvého spojenia pravdivý a nepravdivý je v logických spisoch tol'kokrát označovaný, že nemôže byt' $\mathrm{v}$ žiadnom prípade považovaný za nápadnú zhodu. Druhá údajná zhoda (Bobzien 2021, 157) naznačuje len všeobecne známu klasifikáciu viet a neoznačuje nejakú špecifickú propozičnú konštrukciu. Navyše Frege

${ }^{20}$ Uvádzame číslo strany, na ktorej je uvedená tabul'ka, a poradové čísla riadkov: 158, 2., 3.; 160, 2., 4.; 161, 2.; 170, 1. až 4.; 171, 1. až 3 . 
hovorí o význame niektorých typov viet a dáva ich na tú istú úroveň ako propozíciu, myšlienku (Gedanke), ${ }^{21}$ pričom spojenie coordinirte Arten ani jeho významový ekvivalent sa v jeho nemeckom texte vôbec nevyskytuje. Na druhej strane v Prantlovom komentári text nasleduje značne odlišne - uvedením dvoch druhov otázok a pokračuje klasifikáciou viet.

Ostatných 19 zhôd názvov a krátkych nevetných spojení si mal Frege vziat' priamo z gréčtiny. To je podobná situácia ako pri identifikovaní spoločných jednotiek v DNA rôznych druhov organizmov. DNA všetkých eukaryotických organizmov je vystavaná z rovnakých štyroch základných jednotiek (adenín, guanín, cytozín, tymín). Napriek tomu celková stavba organizmov rôznych druhov je odlišná a je určená odlišnými poradiami týchto jednotiek. Podobne základné logické pojmoslovie odlišných teórií predikátovej logiky bude zhodné, ale teórie vo svojej výstavbe môžu byt' odlišné. K rozdielom týchto teórií sa vrátime. Pre zhody, ktoré sa týkajú obsahu, je príznačné, že Bobzien ich našla vo Fregeho prácach, vydaných takmer výlučne po roku 1918, vrátane posmrtne vydaných prác. To už Frege mal všetko podstatné dávno napísané a publikované.

\section{Nápadné zhody len na základe údajného vyplývania?}

Špeciálny typ zhôd predstavujú dvojice formulácií, pri ktorých je pri jednej alebo dokonca pri oboch uvedené, že vyplýva/-jú z textu, alebo z kontextu. ${ }^{22}$ Spolu 18 zhôd je takto dopracovaných na základe údajného vyplývania. Tu sa však dokazovanie plagizovania dostáva do konfrontácie s hypotézou, ktorú Bobzien nazýva fascinujúcou situáciou, že by mohli nejakí logici, medzi ktorými je viac ako dvojtisícročné obdobie, príst' nezávisle s rovnakými všeobecnými ideami obsahu a rovnakou koncepciou propozičnej logiky (Bobzien 2021, 204).

Naproti tomu napríklad Christopher J. Martin si myslí, že propozičná logika bola objavená na západe snád' trikrát - stoikmi, Abelardom spolu s logikmi dvanásteho storočia a Fregem (Martin 1991, 303).

Bobzien však nie je v hodnotení tejto možnosti konzistentná. Nemôžeme považovat' len za kuriozitu fakt, že v práci o stoickej logike ako sekventovej logike (Bobzien, 2019) to pre prípad Gentzenovej a stoickej logiky už nepovažuje vôbec za fascinujúce, ked’že tvrdí, že stoická teória dôkazu má hlavné znaky Gentzenovho sekventového kalkulu: Gentzenovi od stoikov nezávislý objav zhodného systému logiky zo záhadných dôvodov praje, ale Fregemu nie. Nevysvetl'uje však prečo.

${ }^{21}$ Frege $(1892,38)$ : „Ein Befehl, eine Bitte sind zwar nicht Gedanken, aber sie stehen doch mit Gedanken auf derselben Stufe.“

${ }^{22}$ Uvádzame číslo strany, na ktorej je uvedená tabul'ka, a poradové čísla riadkov: 156, 2.; 163, 1., 3.; 165, 1.; 166, 1. (obe formulácie), 3., 4. (obe); 167, celá; 170, 3., 4.; 171, 2. (obe), 3. (obe), 4.; 175, 2., 4.; 182, 2., 4.; 197, 3. 
Bobzien navyše zrejme netuší, že Tichý sa čudoval, že Gentzen Fregeho systém základných zákonov aritmetiky (Grundgesetze der Arithmetik) nikdy nezmieňoval: ${ }^{23}$ „To je čudné nielen preto, že systémy, ktoré (Gentzen) zmienil, sú tak silne odvodené z Fregeho, ale špeciálne preto, že Fregeho systém bol ovel'a bližší Gentzenovmu vlastnému než akýkol'vek iný v čo najmenšom zameraní sa na axiómy“ (Tichý 1988, 252).

Tichý dodáva: „V skutočnosti niektoré z Gentzenových uzáverov (Schlussweisen) sú len štylistické varianty zodpovedajúcich pravidiel Grundgesetze s jediným, a to terminologickým rozdielom..." a nasleduje podrobný prehl'ad zhodných pravidiel (Tichý 1988, 252). Napokon Tichý zosilňuje myšlienku zhodnosti systémov:

„Ale nie sú to len Gentzenove jednotlivé pravidlá, ktoré sú anticipované v systéme Grundgesetze. Nahliadaním každej formuly ako spočívajúcej z hlavnej zložky a určitého počtu (možno nula) podzložiek - pohl’ad zvýraznený jeho dvojdimenzionálnym zápisom - Frege anticipoval samu základnú ideu Gentzenovho prístupu. Dávno pred Gentzenom Frege prišiel s nápadom, že krok v odvodzovaní je najlepšie reprezentovaný ako zložený z antecedentu a konzekventu“ (Tichý 1988, 252).

Podobne ako Gentzen, ani Bobzien sa v článku o sekventovej logike u stoikov nijako nezmieňuje o Fregeho Grundgesetze.

Takže keby sme to trochu prehnali, ale určite nie viac ako Bobzien v prípade Fregeho a stoikov, podl'a uvedeného Gentzen zrejme (možno) plagizoval Fregeho. Ked'že ten zas mal plagizovat' stoikov, tak Gentzen sprostredkovane plagizoval stoikov. K tejto prehnanej hypotéze sa ešte vrátime.

\section{Skrytý podklad pre kontinuitu}

Pre nás je fascinujúcou okolnost'ou skôr fakt z opačnej perspektívy: ako je možné, že už pred viac ako dvoma tisíckami rokov l'udstvo objavilo logiku, ktorá vel'mi dobre zodpovedala aj potrebám vedy (matematiky) devätnásteho storočia? Ako vysvetl'ujúcu odpoved' sme predložili rekonštrukciu úsudku o nesúmeratel’nosti uhlopriečky so stranou štvorca v stoickej logike (2006, 297 a n.). Sama Bobzien rekonštruuje stoickú logiku len ako sekventový propozičný kalkul (Bobzien 2019), na rozdiel od našej rekonštrukcie stoickej logiky ako predikátovej logiky.

Rovnakost' v logickej teórii propozičnej logiky podporujú najmä dve okolnosti. Prvou je, že v „zadných izbách“ mnohých učebníc logiky, ktoré boli celkovo zväčša výsledkom až nekritickej reprodukcie obsahu tých starších, v skreslenej podobe propozičná logika predsa len nejako preživala. Fregeho zásluhou je, že sa nedal pomýlit’ mnohými deformáciami v expozíciách tejto logiky - pripomeňme napríklad Sigwartovu Logik, kde pri skúmaní hypotetického sylogizmu dominuje skúmanie obsahovej súvislosti medzi antecedentom a konzekventom bez schopnosti od toho abstrahovat'

${ }^{23}$ Všeobecne Fregeho zmieňoval, napríklad (1934/5, 176; 1969, 68). 
a presne pochopit' podmienky pravdivosti materiálnej implikácie. Frege aj túto abstrakciu vykonal bezchybne a prišiel v roku 1879 s originálnym a neobyčajne presným projektom predikátovej logiky, ktorá obsahovala aj propozičnú logiku, zbavenú nánosov a deformácií optiky kategorického sylogizmu. Podl'a tohto projektu bez vel'kých zmien o tridsat' rokov neskôr, ku koncu svojho učitel'ského pôsobenia, učil ešte Carnapa (1910 - 1914) (Frege 2004, 19 a n.) ${ }^{24}$ a príležitostne aj Wittgensteina (1911 - 1913) a iných.

Druhou okolnost'ou, ktorá podporuje utvorenie rovnakých logík, je silná kontinuita systémovej stránky jazykov, ktorú sme už spomenuli. Tá pochádzala z dielní gréckych filozoficko-lingvistických škôl a výrazne sformovala latinskú gramatiku: ,... zrod rímskej jazykovedy vnímame ako výsledok recepcie a prepracovania gréckych vzorov“ (Buzássyová 2016, 8) Hoci v nej neskôr prevládal vplyv aristotelovskej gramatickej školy, predsa sa prostredníctvom priameho vplyvu latinskej gramatiky na gramatiky národných jazykov mnohé pôvodné formálne schémy zo stoickej školy zachovali v používaní syntaktických konštrukcií, či už ide o konštrukcie zložených spojkových operátorov, konštrukcie súvetí pomocou vzt'ažných dvojíc na vyjadrenie všeobecnosti (podmienkové spojenie a anafora) a pod. Potvrdením tejto tradície sú najmä reprodukované schémy formulácií $\mathrm{v}$ ustanoveniach právnych noriem aj $\mathrm{v}$ dnešných dňoch v národných jazykoch, ktoré prevažujú nad aristotelovskými schémami (Gahér, Števček 2018, 211, pozn. 191, 192).

\section{Rozdiely medzi stoickou a Fregeho logikou}

Uvedenie rozdielov medzi stoickou a Fregeho logikou samo osebe nezbavuje Fregeho obvinenia z možného plagizovania. Napriek tomu však povaha niektorých rozdielov k takémuto záveru môže výrazne prispiet'.

Najväčší rozdiel môžeme identifikovat' v odlišných sémantických schémach, preto by sme nemali hovorit', že $\mathrm{v}$ týchto koncepciách ide o totožné všeobecné koncepty obsahu. Stoická sémantická schéma je odlišná od Fregeho. U stoikov je označované (lekton) vždy netelesné (abstraktné), ktoré sa telesného len týka. Jazykový výraz (plnovýznamový článkovaný hlas) ${ }^{25}$ Dión označuje lekton Dión a týka sa Dióna (Gahér 2000, 89; 2006, 77).

Pre Fregeho je denotát (Bedeutung) empirických výrazov predmet $\mathrm{z}$ časopriestoru, alebo je súborom takýchto predmetov, respektíve n-tíc takýchto predmetov

\footnotetext{
${ }^{24}$ Podl'a Carnapa sa Frege zriedkakedy pozeral do auditória: „Normálne sme videli len jeho chrbát, ked'že kreslil divné diagramy z jeho symbolizmu na čiernu tabul'u a vysvetl'oval ich. Žiadny študent sa nikdy neopýtal nejakú otázku ani neurobil poznámku, či už počas prednášky alebo po nej.“ 25 „sémainusa enarthros fóné“ (Buzassyová 2016, 73).
} 
a abstraktné je to, čo je vyjadrené - zmysel (Sinn) výrazov. Výraz Etna označuje vrch Etna a vyjadruje zmysel, spôsob danosti tohto vrchu (Frege 1979a, 243). ${ }^{26}$

Pri porovnávaní stoickej a Fregeho logiky by sme nemali hovorit' o rozdieloch alebo zhodách (o tej istej) koncepcii propozičnej logiky, ako uvádza Bobzien (2021, 204), ale o koncepciách predikátovej logiky, z ktorej každá propozičnú logiku obsahuje. Zo zlomkov stoickej logiky sa zrejme nedá jednoznačne a do detailov rekonštruovat' celý systém - zrejme išlo o poloformálny pravidlový systém, v ktorom boli symboly pre výrokové premenné, ale nenašli sa špeciálne symboly pre indivíduové premenné ani pre predikáty. Medzi základnými výrokovými spojkami nebola nevylučujúca disjunkcia.

Fregeho systém je kompletne symbolický - explicitne sú definované symboly pre operátory (spojky, kvantifikátory) a ako jedna zo základných spojok je nevylučujúca disjunkcia. Originalita Fregeho systému je nepriamo podporovaná aj tým, že uňho nenájdeme ani jednu výpožičku stoického príkladu vety, súvetia či úsudku, hoci ako generáciami vybrúsené a overené by v prípade, že by boli preňho naporúdzi, boli určite lákavé. Bobzien žiadnu takúto výpožičku nenašla, a preto ponúka vždy len zhodu všeobecných schém, logických foriem takýchto súvetí a úsudkov. Ale ved' ak išlo o zhodnú logickú teóriu, tak tieto schémy musia byt' zákonite zhodné.

Ovel'a reálnejšie vysvetlenie prípadu nadväznosti stoici - Frege - Gentzen ako plagizovania je vo svetle našich zistení a záverov založené na tom, že išlo o nezávislé objavy. Stoici vypracovali poloformálny pravidlový systém predikátovej logiky, ktorý nezávisle od nich znovuojavil Frege (Pojmové písmo 1879) a išiel v mnohých ohladoch zretel'ne d’alej ako oni. V Základných zákonoch aritmetiky (1893 - 1903) Frege predložil projekt logicizmu, kde okrem iného predstavil základné idey sekventového kalkulu pre predikátovú logiku. Gentzen (1934) rozpracoval jednak systémy prirodzenej dedukcie (predpokladové systémy logiky), podobné stoickému systému a systémy sekventového kalkulu, ktoré boli podobné Fregeho systému v Grundgesetze; Gentzen však išiel zretel'ne d’alej ako Frege.

\section{Záver}

Preverili sme všetky prípady zhôd, ktoré Bobzien predložila na potvrdenie ňou vyslovenej hypotézy, že Frege plagizoval stoikov. Podl’a nás hypotéza o Fregeho plagizovaní stoikov má vel'a slabých miest a trhlín a nemá dostatočnú oporu v textovej evidencii a faktoch. Prameňom plagizovania má byt' jedna kapitola, najmä však dve strany z knihy, v ktorej sám autor Prantl stoickú logiku neuveritel'ne znevažoval. Ďalej Frege mal odhalit' na prvý pohl'ad to, čo Bobzien pôvodne pred vyše dvadsiatimi rokmi nezbadala ani po podrobnom štúdiu. Klúčovým mala byt' formulácia všeobecnej

${ }^{26}$ Bližšie o tom Gahér (1999, 351). 
propozície v prirodzenom jazyku pomocou implikácie a anafory, ktorú mal Frege prevziat' od stoikov, hoci v Prantlovom texte je len jeden príklad vety s touto štruktúrou. Naopak, $\mathrm{v}$ bežnom jazyku a v súdobých právnych textoch bolo príkladov takýchto viet, ktoré mohli Fregeho inšpirovat', neúrekom. Ahistoricky pôsobí prisudzovanie stoikom názoru na predikát ako na istý druh funkcie, ked’že s týmto vysvetlením prišiel práve až Frege. Vel'ká čast' príkladov významových zhôd je založená len na zhodách osihotených pojmov či vel'mi jednoduchých nepropozičných pojmových spojení, čo je pri podobných koncepciách s rovnakým pojmoslovím zákonité. Významný počet zhôd Bobzien prezentovala len na základe údajného vyplývania z textov, čo nemôže byt' preukazné pre plagizovanie. Bobzien na jednej strane nezvážila mnohé podklady pre kontinuitu výkladu napríklad takzvaného hypotetického sylogizmu, ktorý - hoci sa považoval za druhoradý voči aristotelovskej logike, predsa - sa nachádzal v dostupných učebniciach logiky. V neposlednom rade nerešpektovala mnohé rozdiely medzi stoickou a Fregeho logikou, pričom treba opravit' jej názor - nešlo o koncepcie propozičnej, ale predikátovej logiky. Toto všetko nás vedie k záveru, že Bobzien nepredložila také fakty a ich súvislosti, ktoré by potvrdzovali hypotézu o Fregeho plagizovaní stoickej logiky. Frege jednoducho v tomto zmysle nebol plagiátor.

\section{Literatúra}

ALDRICH, H. (1750): Artis Logicae Compendium. Oxford: E Theatro Sheldoniano.

ARISTOTELES (1961): První analytiky. (Organon III). Prel.: A. Kř́žž. Praha: ČSAV.

BOBZIEN, S. (2000): Wholly Hypothetical Syllogisms. Phronesis, 45 (2), 87 - 137. DOI: http://dx.doi.org/10.1163/156852800510144

BOBZIEN, S. (2019): Stoic Sequent Logic and Proof Theory. History and Philosophy of Logic, 40 (3), 234 - 265. DOI: https://doi.org/10.1080/01445340.2019.1579624

BOBZIEN, S., SHOGRY, S. (2020): Stoic Logic and Multiple Generality. Philosophers' Imprint, 20 (3), 1 - 36. [online] Dostupné na: http://hdl.handle.net/2027/spo.3521354.0020.031 (Navštívené: 20. 6. 2021).

BOBZIEN, S. (2021): Frege plagiarized the Stoics. In: Themes in Plato, Aristotle, and Hellenistic Philosophy. Keeling Lectures 2011 - 2018, 149 - 206. [online] Dostupné na: https://philpapers.org/rec/BOBFPT (Navštívené: 18. 6. 2021).

BUZÁSSYOVÁ, L. (2016). Od hlasu k hláske. Z dejín antickej náuky o reči. Bratislava: Vydavatel'stvo Univerzity Komenského.

DIOGENES LAERTIOS (1954): Životopisy slávnych filozofov I - II. Prel. M. Okál. Bratislava: Slovenská akadémia vied.

DUMMETT, M. (1973): Frege: Philosophy of Language. New York: Harper \& Row.

DUMMETT, M. (1991): Frege and Other Philosophers. Oxford: Oxford University Press.

SEXTUS EMPIRICUS (1914): Adversus Dogmaticos libri quinque In: Mutschmann, I. H. - Mau, J.: Opera, Volume II. Stuttgart - Leipzig: B. G. Teubner. Reprinted Stuttgart - Leipzig: B. G. Teubner, 1958.

SEXTUS EMPIRICUS (1958): Pyrrhoneion Hypotyposeon libri tres. In: Mutschmann, I. H. - Mau, J. : Opera, Volume I, 2nd ed. Stuttgart - Leipzig: B. G. Teubner. [PH] 
GABRIEL, G. - DATHE, U. (eds.) (2000): Gottlob Frege - Werk und Wirkung. Tranl. by Kai F. Wehmeier Kleinen Paderborn. Münster: Mentis, 267 - 281.

GABRIEL, G., HÜLSER, K., SCHLOTTER, S. (2009): Zur Miete bei Frege - Rudolf Hirzel und die Rezeption der stoischen Logik und Semantik in Jena. History and Philosophy of Logic, 30 (4), $369-388$

GABRIEL, G., SCHLOTTER, S. (2017): Frege und die kontinentalen Ursprünge der analytischen Philosophie. Münster: Mentis.

GAHÉR, F. (1999): Dva druhy indivíduí alebo na čo sa vzt'ahujú vlastné mená. Filozofia, 54 (6), $351-376$.

GAHÉR, F. (2000): Stoická sémantika a logika z pohl’adu intenzionálnej logiky. Bratislava: Stimul.

GAHÉR, F. (2006): Stoická sémantika a logika z pohl’adu intenzionálnej logiky, 2. vyd. Bratislava: Univerzita Komenského.

GAHÉR, F., BIELIK, L. (2013): Prečo len (nutné) pravdy ako predpoklady deduktívnych úsudkov? Organon F, 20 (2), 75 - 97.

GAHÉR, F. (2016): Metóda ako procedúra. Filozofia, 71 (8), 629 - 643.

GAHÉR, F. (2019): Je Mill naozaj predchodca známeho vysvetlenia kontrafaktuálov? Filozofia, 74 (4), $259-277$.

GAHÉR, F., ŠTEVČEK, M. (2018): Právo a logika. In: Gábriš, T. (ed.): Aktuálne otázky teórie práva. Bratislava: Wolters Kluwer, 209 - 234.

GENTZEN, G. (1934/1935): Untersuchungen über das logische Schliessen. Mathematische Zeitschrift 39, 176 - 210, 405 - 431. Translated as 'Investigations into Logical Deduction'. In: Szabo, M. (ed.): The Collected Papers of Gerhard Gentzen. Amsterdam: North-Holland 1969, $68-131$.

HEIS, J. (2013): Frege, Lotze, and Boole. In: Reck, E. H. (ed.): The Historical Turn in Analytic Philosophy. History of Analytic Philosophy. London: Palgrave Macmillan. DOI: https://doi.org/10.1007/978-1-137-30487-2_6

HILL, C. O. (1995): Frege's Letters. In: Hintikka, J. (ed.): From Dedekind to Gödel. Dordrecht: Kluwer, $97-118$.

HIRZEL, R. (1879): De logica Stoicorum. In: Satura philologa. Hermanno Sauppio obtulit amicorum Conlegarum Decas. Berlin: $61-78$.

FRAŇO, P. (2013): (Bez)mocný osud. Ciceronova interpretácia Problematiky osudu v spise De Fato. Pusté Úl'any: Schola Philosophica.

FREGE, G. (1879): Begriffsschrift, eine der arithmetischen nachgebildete Formelsprache des reinen Denkens. Halle: von Louis Nebert. Reprinted in Angelelli, I. (ed.) (1964): Begriffsschrift und andere Aufsaetze. Hildesheim: Georg Olms.

FREGE, G. (1884): Die Grundlagen der Arithmetik: eine logisch mathematische Untersuchung über den Begriff der Zahl, Breslau: von Wilhelm Koebner. Preklad P. Balko (2002): Základy aritmetiky. Bratislava: Veda.

FREGE, G. (1891): Funktion und Begriff, Vortrag, gehalten in der Sitzung vom 9. Januar 1891 der Jenaischen Gesellschaft für Medizin und Naturwissenschaft. Jena: von Herman Pohle. (Reprinted in [FBB], 17 - 39.)

FREGE, G. (1892a): Über Sinn und Bedeutung. Zeitschrift für Philosophie und philosophische Kritik 100, 25 - 50. O zmysle a denotáte. Preklad A. Riška (1992). Filozofia, 47 (6), 349 - 363.

FREGE, G. (1892b): Über Begriff und Gegenstand. Vierteljahresschrift für wissenschaftliche Philosophie 16, 192 - 205. Preklad J. Seewaldová (2000): O pojme a predmete. Organon F, 7 (1), $29-39$.

FREGE, G. (1893): Grundgesetze der Arithmetik. Begriffsschriftliche abgeleitet von. Jena: Reprografische Nachdruck (1966) Hildensheim: Georg Olms,. Basic Laws of Arithmetic, 2 vols. Ebert, P. A. - Rossberg, M. (trans. and eds.). Oxford: Oxford University Press.

FREGE, G. (1896): Lettera del sig. G. Frege all'Editore. Jena, den 29 Sept. Rivista di Matematica, $6,53-59$ 
FREGE, G. (1918a): 'Der Gedanke. Eine Logische Untersuchung', Beiträge zur Philosophie des deutschen Idealismus I (1918 - 1919), 58 - 77. (Reprinted in [LU], 30 - 53).

FREGE, G. (1918b): 'Die Verneinung. Eine Logische Untersuchung'. Beiträge zur Philosophie des deutschen Idealismus I (1919), 143 - 157. (Reprinted in [LU], 54 - 71).

FREGE, G. (1923): 'Logische Untersuchungen. Dritter Teil: Gedankengefüge', Beiträge zur Philosophie des deutschen Idealismus III (1923 - 1926), 36 - 51. (Reprinted in [LU], 72 - 91).

FREGE, G. (1969): Nachgelassene Schriften. Hermes, H. - Kambartel, F. - Kaulbach, F. (eds). Hamburg: Felix Meiner Verlag.

FREGE, G. (1972): Conceptual Notation and Related Articles. Trans. and ed. By T. W. Bynum. Oxford: Oxford University Press.

FREGE, G. (1975): Funktion, Begriff, Bedeutung:fünf logische Studien. Patzig, G. (ed.). Göttingen: Vandenhoeck \& Ruprecht. [FBB]

FREGE, G. (1979a): Logik in der Mathematik. In.: Hermes, H. - Kambartel, F. - Kaulbach, F. (eds.): Nachgelassene Schriften. Hamburg: Felix Meiner Verlag, $219-270$.

FREGE, G. (1979b): Posthumous Writings. Trans. P. Long and R. White. Hermes, H. - Kambartel, F. - Kaulbach, F. (eds). Oxford: Oxford University Press.

FREGE, G. (1980): Philosophical and Mathematical Correspondence. Trans. H. Kaal. - Gabriel, G. et al.(eds.). Chicago: Basil Blakwell.

FREGE, G. (1984): Collected Papers on Mathematics, Logic, and Philosophy. Trans. M. Black et al., McGuinness, B. (ed.). New York: Basil Blakwell .

FREGE, G. (1993): Logische Untersuchungen. Patzig, G. (ed.), Göttingen: Vandenhoeck \& Ruprecht. [LU]

FREGE, G. (2004): Frege's Lectures on Logic. Carnap's Student Notes 1910 - 1914. Erich, H. Awodey, S. (eds.). Chicago: Reck, Carus.

KNEALE, M., KNEALE, W. (1962): The Development of Logic. Oxford: Clarendon Press.

LEIGH, F. (ed.) (2021): Themes in Plato, Aristotle, and Hellenistic Philosophy. Keeling Lectures 2011 - 2018. Institute of Classical Studies, University of London Press, London. [online]. Dostupné na: http://humanities-digital-library.org/index.php/hdl/catalog/book/keeling-lectures (Navštívené: 20. 6. 2021).

LOTZE, H. (1843): Logik. Berlin: Weidmann.

ŁUKASIEWICZ, J. (1927): O logice stoików. Przeglad Filozoficzny. 30, 278 - 279.

MARKO, V. (2020): On Cicero's Fabius argument. Filozofia, 75 (8), 677 - 692. DOI: https://doi.org/10.31577/filozofia.2020.75.8.5

MARTIN, C. J. (1991): The Logic of Negation in Boethius. Phronesis, 36 (3), 277 - 304.

PEANO, G. (1895): Dr. G. Frege. Grundgesetze der Arithmetik, begriffsschriftlich abgeleitet. Erster Band. Jena 1893, pag. XXXII+254. Rivista di matematica 5, $122-128$.

PEANO, G. (1896): Risposta. Rivista di Matematica, 6, 60 - 61.

PRANTL, C. (1855): Geschichte der Logik im Abendland. Leipzig: S. Hirzel, 1927 Leipzig (2. vyd.).

SEXTUS EMPIRICUS (1970): Przeciw logikom. Prel. I. Dąmbska. Warszawa: Państwowe Wydawnictwo Naukowe.

SIGWART, H. (1835): Handbuch zu Vorlesungen über die Logik, 3. durchaus vermehrte und verbesserte Auflage Tübingen: Osiander.

SIGWART, Ch. (1889): Logik. Die Lehre vom Urteil, Begriff und vom Schluss, I. pôvodne 1873, Laupp. Tübingen. 2. doplnené vydanie. Freiburg: J. C. B. Mohr.

SLUGA, H. (1975): Frege and the Rise of Analytical Philosophy. Inquiry, 18, $471-487$.

SLUGA, H. (1976): Frege as a Rationalist. In: Studien zu Frege. Vol. 1, edited by M.Schirn. Stuttgart-Bad Canstatt: Frommann.

SLUGA, H. (1977): Frege's Alleged Realism. Inquiry, 20, 227 - 242.

SLUGA, H. (1980): Gotlog Frege. London: Routledge. 
SLUGA, H. (1984): Frege: the early years. In: Rorty, R. - Schneewind, J. - Quentin Skinner, Q. (eds.): Philosophy in History: Essays in the Historiography of Philosophy. New York: Cambridge University Press, $329-356$.

SLUGA, H. (1987): Frege against the Booleans. Notre Dame Journal of Formal Logic, 28 (1), 80 - 98. TICHÝ, P. (1988): The Foundations of Frege's Logic. Berlin - New York: W. de Gruyter.

Internetové zdroje:

Allgemeines Landrecht für die Preußischen Staaten (01.06.1794), Erster Theil | opinioiuris.de (Navštívené 3. 8. 2021).

Práca na tomto článku bola podporená projektom č. APVV-17-0057 Analýza, rekonštrukcia a hodnotenie argumentov a projektom VEGA č. 1/0197/20, Postoje v komunikácii a argumentácii: sémantické a pragmatické aspekty.

František Gahér

Katedra logiky a metodológie vied

Filozofická fakulta UK v Bratislave

Gondova 2

81499 Bratislava

Slovenská republika

e-mail: frantisek.gaher@uniba.sk

ORCID ID: https://orcid.org/0000-0001-6892-1429 